九州大学学術情報リポジトリ

Kyushu University Institutional Repository

Comparison of Dry Matter Production and Photosynthetic Rate against Different Planting Dates between Late and Early Maturing Soybean cultivars in Paddy Field

Cho, Jin-Woong

Division of Plant Science and Resources, Collage of Agricultural and Life Science, Chungnam National University

Yamakawa, Takeo

Laboratory of Plant Nutrition, Department of Plant Resources, Faculty of Agriculture, Kyushu University

https://doi.org/10.5109/12846

出版情報: 九州大学大学院農学研究院紀要. 53 (2)，pp. 389-393，2008-10-28. Faculty of Agriculture, Kyushu University

バージョン：

権利関係 : 


\title{
Comparison of Dry Matter Production and Photosynthetic Rate against Different Planting Dates between Late and Early Maturing Soybean cultivars in Paddy Field
}

\author{
Jin-Woong CHO $^{1}$ and Takeo YAMAKAWA* \\ Laboratory of Plant Nutrition, Division of Soil Science and Plant Production, \\ Department of Plant Resources, Faculty of Agriculture, Kyushu University, \\ 6-10-1 Hakozaki, Fukuoka 812-8581, Japan \\ (Received June 20, 2008 and accepted July 16, 2008)
}

\begin{abstract}
This experiment carried out in a southwestern Korea on a commerce silt loam soil at paddy field. Pungsannamulmong (PSNK), a yellow seed color type, was a relatively high-yielding late maturing cultivar and Nogchaekong (NCK), green seed color type, was a relatively low-yielding early maturing cultivar. Two seeds per hill were sowed with the planting density of $70 \times 10 \mathrm{~cm}$ on May 20 and June 20, 2007. Fertilizer was applied prior to planting at a rate of 3.0-3.0-3.4 g (N-P-K) per $\mathrm{m}^{2}$ by all basal fertilizations. Experimental design was a randomized complete block with three replications. The days from planting to flowering date (R1) and maturing date were longer in PSNK than in NCK on two planting dates. Each seed yield of PSNK planted on May 20 or June 20, which was 282 or $248 \mathrm{~g} \mathrm{~m}^{-2}$, was higher than that of NCK, which was 244 and $213 \mathrm{~g} \mathrm{~m}^{-2}$, respectively. Also, the number of pod, number of seed and seed per pod were higher in PSNK than in NCK. The leaf area and top dry matter were higher in PSNK than in NCK, especially, at 60 and 70 days after emergence, respectively. Photosynthetic rate $\left(P_{N}\right)$ at flowering stage $(R 1)$, there was no significant difference between cultivars in the uppermost leaf but there was a significant difference in $\mathrm{P}_{\mathrm{N}}$ of the $7^{\text {th }}$ leaf on seed development stage (R5).
\end{abstract}

\section{INTRODUCTION}

Researches on photosynthesis and dry matter production of soybeans had been achieved based on the population structure, the light-interception characteristics, the photosynthesis of population, and the photosynthesis ability of leaf (Asanome and Ikeda, 1998; Kokubun et al., 1988; Sagawa, 1998; Ookawa et al., 1999). Through out these researches, various factors affecting the photosynthesis of leaf were proved theoretically including the plant type that have light-interception characteristics to get high population photosynthesis (Dornhoff and Shibles, 1970). Also, net production of soybean population was high relationship between plant density, planting type and canopy structure, leaflet orientation, and photosynthetic rate (Ikeda, 2000; Wofford and Allen, 1982).

Increasing soybean yields at late planting dates (after mid June) is major agronomic objectives in southern Korea where was adverse double cropping after winter cereals. In this practice of double cropping, planting dates of soybean are delayed until late June to early July. This delay reduced yield and affected most agronomic characteristics compared with full season soybean (Quattara and Weaver, 1994). Delayed planting reduced the days to maturity (Board and Harville, 1996), reduced the days to flowering, and decreased the length of vegetative and reproductive growths. Late-planted yields can be improved by environmental stresses that slow

\footnotetext{
Division of Plant Science and Resources, Collage of Agricultural and Life Science, Chungnam National University, 305-764, Korea

* Corresponding author (E-mail: yamakawa@agr.kyushu-u. ac.jp)
}

down crop growth rate (CGR) during emergence to R5 stage (Fehr et al., 1971; Board and Harville, 1996) and by narrowing inter-row spacing and increasing plant population (Boquet, 1990). Yield reduction was more pronounced for late maturing cultivars than for early maturing ones (Shin et al., 1992). However, although these reports indicated that late maturing cultivars decreased plant height, number of branches and number of main stem nodes more than early maturing cultivars, others indicated similar with two maturing types or conversely, decrease more early maturing cultivars than late maturing cultivars (Chung, 1988). Also, growth reduction was more cleared for indeterminate cultivars than determinates (Chu et al., 1996; Quattara and Weaver, 1994).

On the other hand, in order to elevate the self-supply, to increase the yield per unit area and to extend the cultivation area of soybean in Korea, it is necessary to extend the cultivation area to paddy fields. However, in case of soybean cultivation in the paddy field, there was one of the important factors in waterlogged which been caused by heavy rainfall or poor drainage at rainy seasons (late June to August). Also, detrimental effects of prolonged rainfall are usually accompanied with an inadequate oxygen supply to sustain root respiration and root availability (Seong et al., 2000).

Therefore, this research carried out to compare between PSNK (late maturing growth, yellow seed and high yield production type) and NCK (early maturing growth, green seed and low yield production type) with the difference of yield production ability using leaf area, dry matter, and photosynthetic rate in soybean community at two planting times. 
Table 1. Chemical properties of soil used for paddy field experiment

\begin{tabular}{|c|c|c|c|c|c|c|c|c|}
\hline \multirow{2}{*}{$\begin{array}{c}\mathrm{pH} \\
(1: 5)\end{array}$} & \multirow{2}{*}{$\begin{array}{l}\text { O.M. } \\
\left(\mathrm{g} \mathrm{kg}^{-1}\right)\end{array}$} & \multirow{2}{*}{$\begin{array}{l}\mathrm{T}-\mathrm{N} \\
(\%)\end{array}$} & \multirow{2}{*}{$\begin{array}{c}\mathrm{P}_{2} \mathrm{O}_{5} \\
\left(\mathrm{mg} \mathrm{kg}^{-1}\right)\end{array}$} & \multicolumn{3}{|c|}{ Ex. Cat. $\left(\mathrm{cmol}_{\mathrm{c}} \mathrm{kg}^{-1}\right)$} & \multirow{2}{*}{$\begin{array}{c}\mathrm{EC} \\
\left(\mathrm{dS} \mathrm{m}^{-1}\right)\end{array}$} & \multirow{2}{*}{$\begin{array}{c}\text { CEC } \\
\left(\mathrm{cmol}_{\mathrm{c}} \mathrm{kg}^{-1}\right)\end{array}$} \\
\hline & & & & $\mathrm{K}$ & $\mathrm{Ca}$ & $\mathrm{Mg}$ & & \\
\hline 5.8 & 2.06 & 0.19 & 235 & 0.51 & 0.19 & 0.22 & 0.23 & 3.5 \\
\hline
\end{tabular}

\section{MATERIALS AND METHODS}

This experiment carried out at a farm affiliated to Chungnam National University in the southwestern Korea with a commerce silt loam soil at paddy field. Soybean (Glycine max L. Merr.) cv. Pungsannamulkong (PSNK), a determinate growth habit, was a relatively high-yielding late maturing cultivar (Suh et al., 1997) and cv. Nogchaekong (NCK), a determinate growth habit, was a relatively low-yielding early maturing cultivar (Kim et al., 2006) were used in this. Several chemical characteristics of used soil were shown in Table 1.

Fertilizer was applied prior to planting at a rate of 3.0-3.0-3.4 g (N-P-K) per $\mathrm{m}^{2}$ as basal fertilization. Weeds, diseases, and insects were controlled by recommended pesticides. Tow seeds were sowed per hill with the planting density of $60 \times 15 \mathrm{~cm}$ at May 20 and June 20, 2007. The cultivated area of experimental plots was about $10.4 \mathrm{~m}^{2}$ per cultivar and planting time. Experimental design was a randomized complete block with three replications.

The plant samples for leaf area and top dry matter were harvested at 20,30,40,50,60,70, 80, and 90 days after emergence. The leaf area was determined by measuring the leaf blades through a leaf area meter (LI-COR Li-3100, USA) and dry matter was determined after drying in a forced-air dryer at $80^{\circ} \mathrm{C}$ for $72 \mathrm{hr}$.

The photosynthesis of completely expanded top and $7^{\text {th }}$ leaves of main stem was measured using a portable photosynthetic apparatus (Li-6400, U.S.A) at flowering stage (R1 by Fehr et al., 1971) and seed development stage (R5). Measurements were taken from 9: 30 in the morning to 1: 30 in the afternoon by six replications of measurements per each cutivar and planting time. The light intensity used to measure the photosynthetic rate was in nature light and in the range of $0-2,000 \mu \mathrm{mol} \mathrm{m}^{-2}$ $\mathrm{s}^{-1}$ photosynthetically active radiation (PAR). The $\mathrm{CO}_{2}$ concentration was $350-380 \mathrm{ppm}$ and the flow rate of the air was $400 \mathrm{ml} \mathrm{min}^{-1}$. And the chlorophyll content was measured using chlorophyll instrument (SPAD 502, Minolta, Japan) with the photosynthesis measurement.

\section{RESULT AND DISCUSION}

\section{Yields and yield components}

Delayed planting on June 20 had a large effect on the seed yield of two soybean cultivars. The seed yield of PSNK planted on June 20 was approximately $34 \mathrm{~g}$ less than that of conventional planting on May 20. Also, the seed yield of NCK planted on June 20 decreased about $30 \mathrm{~g}$ compared to the seed yield of soybean planted on May 20. According to planting dates, the yield reduction of PSNK was more than that of NCK (Table 2). The number of pod and seed per plant also decreased with the delay of planting date. The reduction was more in PSNK than in NCK with on June 20 compared to on May 20. The seed weight of PSNK and NCK decreased on June 20 compared to conventional planting date. Also, the number of pod and number of seed were reduced by delayed planting dates. However, there was no significant difference in delayed planting dates in seeds per pod and seed weight of NCK which was an early matur-

Table 2. Dates of flowering (R1) and maturing (R8) stage, and the days from planting to R1 and R8 stage in planted small seeded soybean cultivars planted on May 20 and June 20, respectively

\begin{tabular}{cccccc}
\hline Cultivars & $\begin{array}{c}\text { Planting time } \\
\text { (Mon. Day) }\end{array}$ & $\begin{array}{c}\text { R1 stage } \\
\text { (Mon. Day) }\end{array}$ & $\begin{array}{c}\text { R8 stage } \\
\text { (Mon. Day) }\end{array}$ & R1 stage & R8 stage \\
\cline { 3 - 5 } PSNK & 5.20 & 7.31 & 10.5 & 72 & 136 \\
NCK & 6.20 & 8.5 & 10.9 & 46 & 111 \\
& 5.20 & 7.8 & 9.20 & 49 & 32 \\
\hline
\end{tabular}

Table 3. Yield and yield components of small seeded soybean cultivars planted on May 20 and June 20 , respectively

\begin{tabular}{|c|c|c|c|c|c|}
\hline Cultivars & $\begin{array}{l}\text { Planting time } \\
\text { (Mon. Day) }\end{array}$ & $\begin{array}{l}\text { No. of pod } \\
\left(\text { no. plant }{ }^{-1}\right)\end{array}$ & $\begin{array}{l}\text { No. of seed } \\
\left(\text { no. plant }{ }^{-1}\right)\end{array}$ & $\begin{array}{l}\text { Seed weight } \\
\left(\mathrm{g} 100 \text { seed }^{-1}\right)\end{array}$ & $\begin{array}{c}\text { Yield } \\
\left(\mathrm{g} \mathrm{m}^{-2}\right)\end{array}$ \\
\hline \multirow{2}{*}{ PSNK } & 5.20 & 76.0 & 109.1 & 12.9 & 282 \\
\hline & 6.20 & 58.9 & 85.6 & 11.4 & 248 \\
\hline \multirow{2}{*}{ NCK } & 5.20 & 55.0 & 85.6 & 10.3 & 244 \\
\hline & 6.20 & 50.7 & 72.8 & 9.8 & 213 \\
\hline
\end{tabular}


ing cultivar.

Lee et al. (1989) and Cho et al. (2004) reported the effect of planting date on yield of soybean cultivars. The yield of late planted soybean reduced more in late maturing cultivars than in early or middle maturing cultivars. This result indicated that the reduction of seed yield according to delay of planting date resulted from insufficiency of seed development due to shorter vegetative periods which affected reproductive stages with sensitive response against a short daytime and high temperature (Table 3).

On the other hand, the flowering date was late in the delay of planting, but days were shorted from emergence to flowering and to maturity (Table 2). When soybean was planted on May 20, the flowering date was earlier about 22 days in NCK on July 8 compared to that of PSNK on July 31. Also, when it planted on June 20, the flowering date was July 22 in NCK, and August 5 in PSNK. Days from emergency to flowering and to maturity also were shorter in NCK than in PSNK with delayed planting dates.

The leaf area of NCK was similar with PNSK across the 50 days from emergence but, in contrast, the leaf area of PSNK was greater than NCK after 50 days after emergence when was planted on May 20. There were no differences between two soybean cultivars planted on June 20 (Fig. 1). The leaf area was measured at 90 days and 80 days after the emergence once these were planted on May 20 and June 20, respectively. The leaf area of PSNK and NCK planted on May 20 were 4.0 and $2.0 \mathrm{~m}^{2}$ at R1 growth stage, respectively but they were reduced as $1.4 \mathrm{~m}^{2}$ and $0.7 \mathrm{~m}^{2}$ at the late planting date of June 20 at the same stage. Top dry matter accumulation was also decreased by the late planting. However, although the growth was discontinued at the flowering stage in determinate type soybeans but the growth was progressively growing after flowering stages in paddy field. Top dry matter of PSNK at flowering stage showed by $992 \mathrm{~g}$ planted on May 20 and $163 \mathrm{~g}$ planted on June 20, and of NCK showed by $287 \mathrm{~g}$ and $72 \mathrm{~g}$, respectively. The top

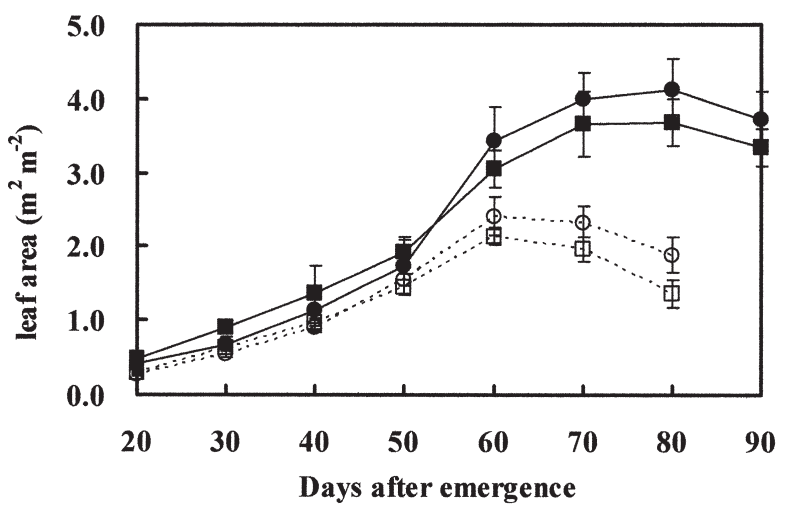

Fig. 1. The change of leaf area of two soybean cultivars after emergence on two planting times. $\square$ and $\square$ indicates PSNK, $\bigcirc$ and indicates NCK. Dark symbol show the planting on May 20, light symbol ( $\square$ and $\bigcirc$ ) show the planting on June 20.

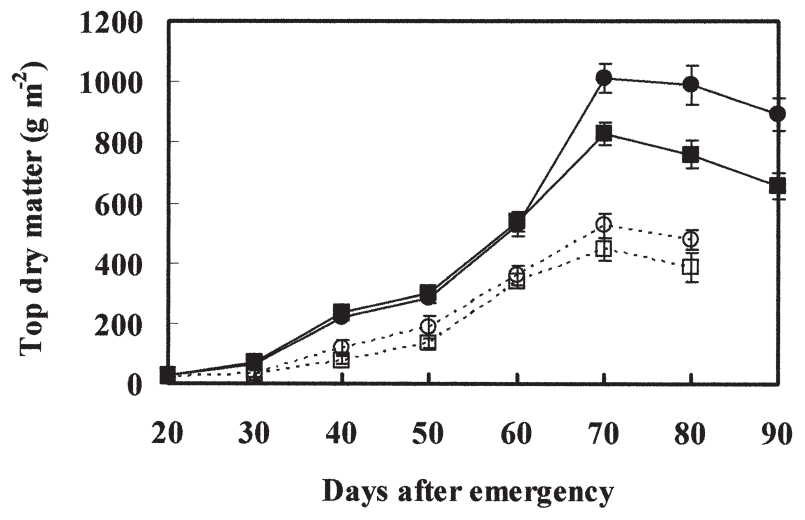

Fig. 2. The top dry matter of two soybean cultivars in days after emergency. $\square$ and $\square$ indicates Punsannamulkong and and $\bigcirc$ indicates NCK. Dark symbol $\square$ and $\mathbf{O}$ show the planting on May 20, light symbol ( $\square$ and $\bigcirc$ ) show the planting on June 20. Each bars is shown mean $\pm \mathrm{SE}$.

dry matter at flowering stage was more reduced by the delay of planting in PSNK than in NCK (Fig. 2). Reduction of the top dry matter in PSNK by the late planting was $83 \%$ on June 20 compared to that on May 20 and that in NCK was $74 \%$.

Cho et al. (2004) reported that there was a high significant difference between dry matter and seed yield of soybean at the flowering stage in drained-paddy field. Ookawa et al. (1999) carried out the study to compare yields of two soybean cultivars concluded that soybean cultivar of higher dry matter production after flowering could attain a higher seed yield. Therefore, in order to obtain the most seed yield, the dry matter production at flowering stage (R1) can be very important of soybean.

\section{Chlorophyll content and photosynthesis}

The chlorophyll content of two soybean cultivars at R1 and R5 stages with two planted dates was shown in Fig. 3. The chlorophyll content ranged as 23-32, 32-38 and 36-45 SPAD value in the $5^{\text {th }}$, the $7^{\text {th }}$ and the upper-

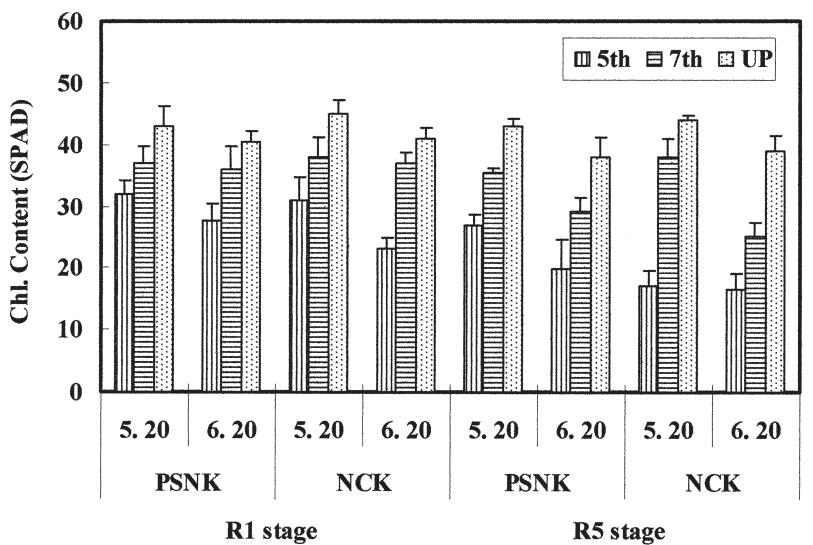

Fig. 3. Chlorophyll content (SPAD value) of the $5^{\text {th }}$, the $7^{\text {th }}$ and the uppermost (UP) leaf of two soybean cultivars at the flowering (R1) and the seed development (R5) stage on two planted dates at paddy field. PSNK; Pungsannamulkong, NCK; Nogchaekong. 
most leaf at R1 stage, respectively and ranged as 16-27, 25-38, and 38-44 SPAD value in the same leaf at R5 stage, respectively. According to the planting date, the chlorophyll content of the plant planted on May 20 at the R1 stage was higher than that planted on June 20. Especially, the difference of the chlorophyll content at the $5^{\text {th }}$ leaf position appeared as significant. By comparing the difference of the chlorophyll content between two cultivars at the $\mathrm{R} 1$ stage, the $7^{\text {th }}$ and the uppermost leaf did not show the differences between two cultivars. But, PSNK showed higher chlorophyll content at the $5^{\text {th }}$ leaf than NCK. The chlorophyll content at the R5 stage ranged 16-27, 25-38, and 38-44 SPAD value at the $5^{\text {th }}$, the $7^{\text {th }}$, and the uppermost leaf, respectively and these contents were less than that at R1 stage. According to the planting date, the chlorophyll content of the plant plated on June 20 was less than that planted on May 20, and the chlorophyll content of PSNK was higher than NCK on the same planting date.

\section{Photosynthetic rate $\left(P_{N}\right)$ and characteristic}

The $\mathrm{P}_{\mathrm{N}}$ of the uppermost and the $7^{\text {th }}$ leaf at $\mathrm{R} 1$ and R5 stages were shown in Fig. 4. The $\mathrm{P}_{\mathrm{N}}$ of the uppermost leaf had no significance between planting dates, and R1 and R5 stages but PSNK showed higher $\mathrm{P}_{\mathrm{N}}$ than NCK. The $\mathrm{P}_{\mathrm{N}}$ of the uppermost leaf was over $30 \mathrm{CO}_{2}$ $\mu \mathrm{mol} \mathrm{m}{ }^{-2} \mathrm{~s}^{-1}$ on two planting dates and at two stages (R1 and R5) in PNSK but NCK showed under $30 \mathrm{CO}_{2} \mu \mathrm{mol}$ $\mathrm{m}^{-2} \mathrm{~s}^{-1}$ of $\mathrm{P}_{\mathrm{N}}$ at the same times (Fig. $4 \mathrm{~A}$ ). $\mathrm{P}_{\mathrm{N}}$ of the middle leaf $\left(7^{\text {th }}\right.$ leaf) was similar with as the delayed planting date in NCK at R1 stage. Meanwhile, at R5 stage, $\mathrm{P}_{\mathrm{N}}$ of NCK showed higher in delayed planting date (on June
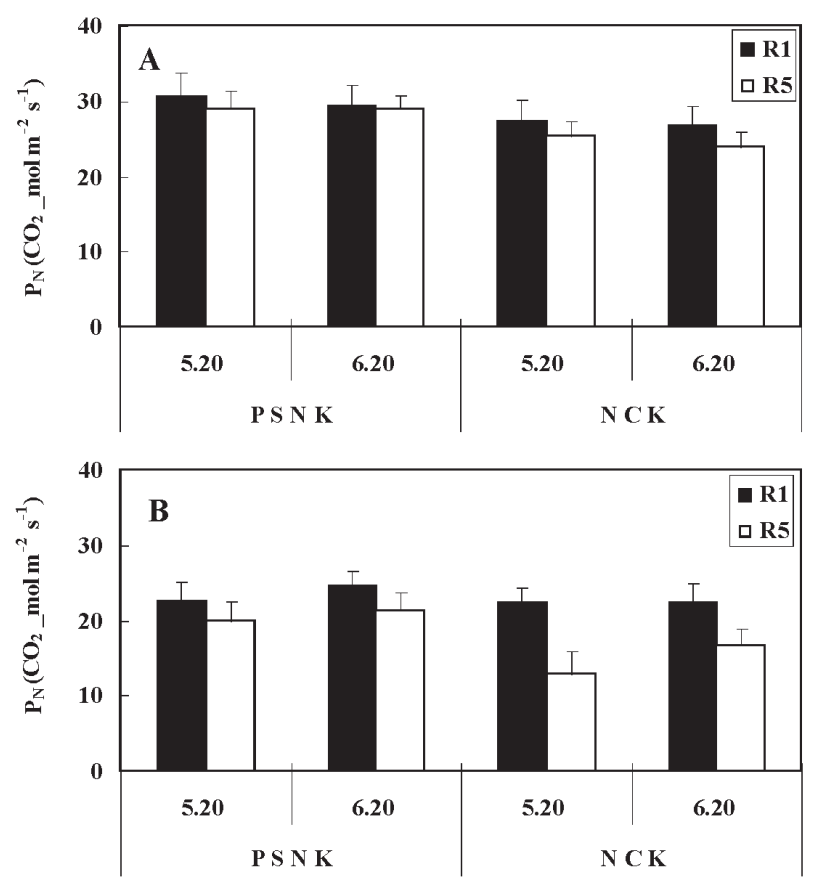

Fig. 4. Photosynthetic rate of the uppermost leaf (A) and the $7^{\text {th }}$ leaf (B) of two soybean cultivars at the flowering (R1) and seed development (R5) stages planted on May 20 and June 20 , respectively. Each bar is shown mean $\pm \mathrm{SE}$.
20) compared to that of conventional planting date (on May 20). The $\mathrm{P}_{\mathrm{N}}$ of the $7^{\text {th }}$ leaf against planting dates and growth stages had no significance in PSNK. The $\mathrm{P}_{\mathrm{N}}$ of PSNK was by $18.9 \mathrm{CO}_{2} \mu \mathrm{mol} \mathrm{m}{ }^{-2} \mathrm{~s}^{-1}$ greater than $12.7 \mathrm{CO}_{2}$

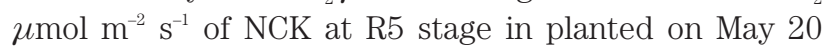
(Fig. 4B), and was by $22.5 \mathrm{CO}_{2} \mu \mathrm{mol} \mathrm{m} \mathrm{m}^{-2} \mathrm{~s}^{-1}$ in PSNK higher than $16.5 \mathrm{CO}_{2} \mu \mathrm{mol} \mathrm{m} \mathrm{m}^{-2} \mathrm{~s}^{-1}$ in NCK on planted June 20. Cho et al. (2003) reported that $\mathrm{P}_{\mathrm{N}}$ at R5 stage among soybean cultivars showed positive correlation with seed yield in middle leaf position, and Sagawa (1997) showed the positive correlation between $\mathrm{P}_{\mathrm{N}}$ of leaf of lower position and yields at the seed development stage. Also, Cho et al. (2003) stated that higher yield of soybean cultivar compared with that of lower yield cultivar caused to increase the $\mathrm{P}_{\mathrm{N}}$ at lower leaf as well as the $7^{\text {th }}$ leaf at early reproduction stage under the delayed planting date. Therefore, from this experiment, the higher seed yield of PNSK compared with that of NCK might cause to increase the $\mathrm{P}_{\mathrm{N}}$ at middle and lower leaf as well as the $7^{\text {th }}$ leaf at the seed development stage under the delayed planting date. Generally, the $\mathrm{P}_{\mathrm{N}}$ of middle and lower leaves had a relationship with the light inten-
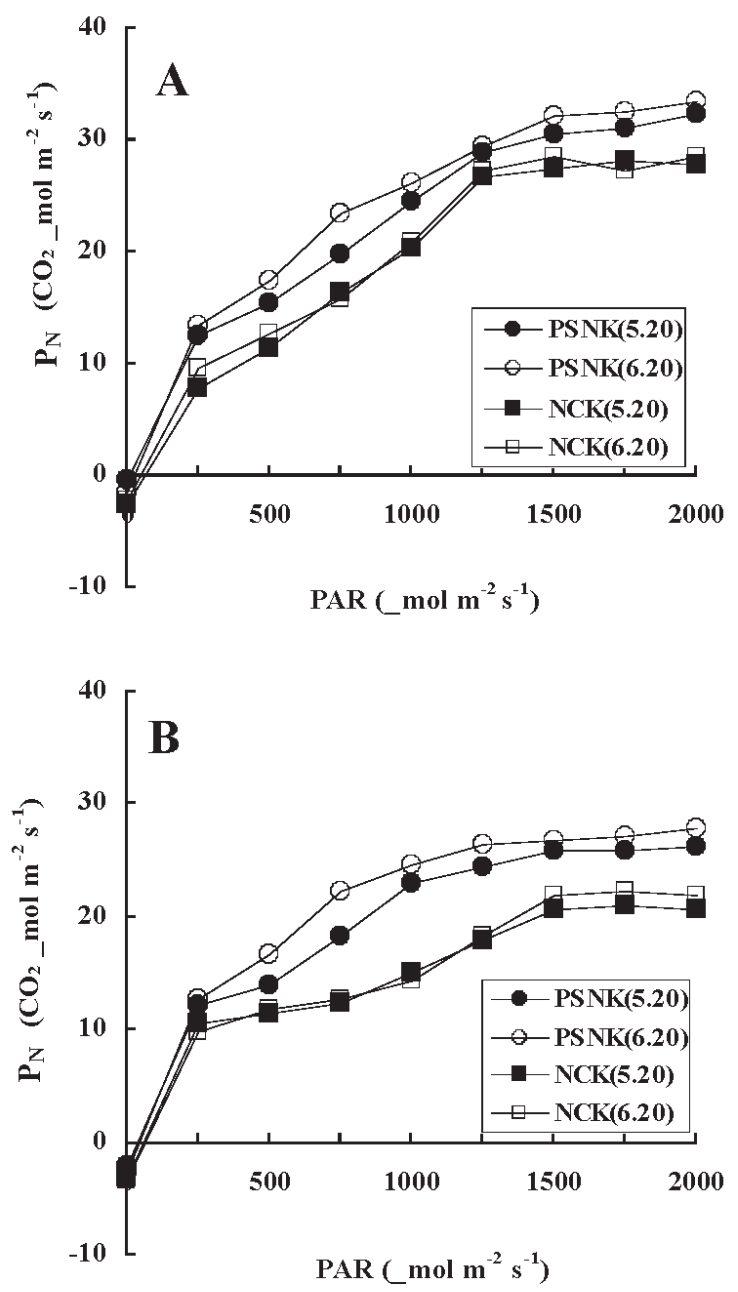

Fig. 5. Change of photosynthetic rate according to $0-2,000 \mu \mathrm{mol}$ $\mathrm{m}^{-2} \mathrm{~s}^{-1}$ of photosynthetically radiation rate (PAR) at the flowering (A) and the seed development (B) stages in $7^{\text {th }}$ leaf of two soybean cultivars planted on May 20 and June 20 , respectively. 
sity character of the leaf, the late planted soybeans had less LAI, and the size of leaf area per plant was smaller compare to that of the conventional planted soybeans. So, the late planted soybeans had higher $\mathrm{P}_{\mathrm{N}}$ of middle and lower leaves although the uppermost leaf had not shown (Cho et al., 2003; Kokubun et al., 1988; Sagawa, 1998). In this experiment, the late planted soybeans showed higher (R5) or similar (R1) $\mathrm{P}_{\mathrm{N}}$ than the conventional planting soybeans, and PSNK had higher $\mathrm{P}_{\mathrm{N}}$ than NCK at R5 stage. On the other hand, the $\mathrm{P}_{\mathrm{N}}$ in two soybeans according to the light intensity at R1 and R5 stages was shown in Fig. 5. The $\mathrm{P}_{\mathrm{N}}$ increased as the light intensity increased. The light saturation point of two soybeans appeared to be the light intensity over 1,500 $\mu \mathrm{mol}$ $\mathrm{m}^{-2} \mathrm{~s}^{-1}$ PAR (photosynthetically active radiation) at the R1 stage (Fig. 5A), but at the R5 stage, the light saturation point reached over $1,250 \mu \mathrm{mol} \mathrm{m}{ }^{-2} \mathrm{~s}^{-1} \mathrm{PAR}$ in PNSK and over $1,500 \mu \mathrm{mol} \mathrm{m}{ }^{-2} \mathrm{~s}^{-1} \mathrm{PAR}$ in NCK. Therefore, the light efficiency showed higher in PSNK than in NCK at R5 stage.

\section{REFERENCES}

Cho, J. W., J. J. Lee and C. S. Kim 2004 Effects of planting dates on growth and yield of soybean cultivated in drained-paddy field. Korean J. Crop Sci., 49: 325-330

Cho, J. W., C. H. Kim and J. D. So 2003 Varietal difference of dry matter production and photosynthesis of middle and lower leaves in soybean. Korean J. Crop Sci., 48: 25-30

Chu, Y. H., K. W. Chung and M. K. Joo 1996 Effect of different planting dates on growth and yield component in two ecotypes of soybean. Korean J. Crop Sci., 41: 86-94
Chung, K. W. 1988 Growth and dry matter accomulation in different ecotypes of soybeans (Glycine max. L). Korean J. Crop Sci., 33: 174-181

Fehr, W. R., C. E. Caviness, D. T. Burmood and J. S. Pennington. 1971 Stage of development descriptions for soybean, Glycine $\max$ (L.) Merrill. Crop Sci., 11: 929-931

Kim, S. D., Y. J. Oh, K. H. Kim, S. K. Suh, S. K. Cho, S. L Park and B. M. Park 2006 Suitable sprout soybean variety "Nogchae" for succeeding crop of garlic and onion in south region. Treat. HARI., 2: 279-281

Kokubun, M., H. Mochida and Y. Asahi 1988 Soybean cultivars difference in leaf photosynthetic rate and its relation to seed yield. Jpn. J. Crop Sci., 57: 743-748

Ma, B. L., M. J. Morrison and H. D. Voldeng 1995 Leaf greenness and photosynthetic rates in soybean. Crop Sci., 35 1411-1414

Ookawa, T., Y. Takase, K. Ishihara and T. Hirasawa 1999 Dry matter production and ecophysiological characteristics between soybean cultivars, Enrei and Tachinagaha. Jpn. J. Crop Sci., 68: 105-111

Quattara, S. and D. B. Weaver 1994 Effect of growth habit on yield and agronomic characteristics of late-planted soybean. Crop Sci., 34: 870-873

Sagawa, S 1998 Varietal difference in photosynthetic rate of middle and lower leaves and its relation to seed yield in soybean plants. Jpn. J. Crop Sci., 67: 221-225

Seung, Y. K., S. H. Lee, Y. H. Kim, S. D. Kim, K. W. Chung and C. S. Moon 1995 Varietal difference of flowering, maturity and yield in response to planting time in soybean. Korean J. Breed., 27: 252-258

Shin, D. C., C. K. Park, I. Y. Baek, I. Y. jung, S. B. Song, H. S. Suh and Y. J. Oh 1995 Early maturing, resistant to disease and loging, small seed size sprouting soybean variety "NCK" RDA. J. Agri. Sci., 37: 139-143

Suh, S. K., H. S. Kim, Y. J. Oh, K. H. Kim, S. K. Cho, Y. J. Kim, S. D. Kim, H. K. Park, M. S. Park and S. Y. Cho 1997 A new soybean variety for sprout with small seed high yielding "PSNK". RDA. J. Agri. Sci., 39: 120-124 